\title{
Leadership Style, Machiavellianism and Fair Play at the School: Interaction of Instructors and Students in Physical Education
}

\author{
Dimitrios Bardas, Alexandra Bekiari \\ Faculty of Physical Education and Sports Science, University of Thessaly, Trikala, Greece \\ Email: sandrab@pe.uth.gr
}

How to cite this paper: Bardas, D. and Bekiari, A. (2019) Leadership Style, Machiavellianism and Fair Play at the School: Interaction of Instructors and Students in Physical Education. Open Journal of Social Sciences, 7, 130-146.

https://doi.org/10.4236/jss.2019.71012

Received: December 6, 2018

Accepted: January 13, 2019

Published: January 16, 2019

Copyright () 2019 by author(s) and Scientific Research Publishing Inc. This work is licensed under the Creative Commons Attribution International License (CC BY 4.0).

http://creativecommons.org/licenses/by/4.0/

\begin{abstract}
In this study, correlations among physical education instructors' leadership style and students' fair play behaviors and Machiavellian tactics were examined. The sample consisted of 292 students ( 151 males, 141 females) of 10 - 15 years old from primary and secondary schools. Three types of questionnaires were completed during physical education courses. Statistically significant differences were observed in perceived instructors' leadership style (more "autocratic" style toward male students and "democratic" toward female), antisocial behaviors by male students and pro-social behaviors by the female ones and Machiavellianism by male students. It has been found that the students of the $5^{\text {th }}$ class of primary school are especially susceptible to see autocratic leadership style on their instructors and to perceive more gamesmanship, cheating, and Machiavellianism on themselves. However, the students of the $3^{\text {rd }}$ class of secondary school tend to see more democratic leadership style on their instructors and to believe that they present more convention and respectfulness to their teammates. Perceived instructors' autocratic leadership style was negatively related to students' prosocial fair play behaviors, while it was positively related to students' antisocial fair play behaviors and Machiavellian tactics. Moreover, leadership style could significantly predict the variables of students' fair play behaviors and Machiavellianism. Three particular profiles have been proposed: the "bad and controlled student", the "respectful and weak student" and the "typical autocratic instructor". Thus, both academic and practical added value is expected to have been produced by the particular research.
\end{abstract}

\section{Keywords}

Leadership Style, Fair Play, Machiavellianism, Physical Education 


\section{Introduction}

\subsection{Literature Review}

The leadership style affects positively the efficiency of attendants [1]. The autocratic leadership style is useful in narrow time frame [2]. Autocratic leadership style is connected with low-level tasks. Accordingly, the leaders should have characteristics democratic leadership style to the growth of performances [3]. The leadership of coaches affected their athletes when these have experience in sports and autocratic leadership style for groups were otherwise at the end of games [4]. Moreover, autocratic leadership style, performance mood and Machiavellianism had positive relations with teachers' verbal aggressiveness [5]. The athletic performance affected from factors as leadership style behavior, the athletes that participated in teams, the content of people in sports by collective extension, in each person in the abstract, in fair play, in democratic attitude, in autocratic behavior, in positive feedback, in democratic leadership style behavior is dominant in the secondary education schools. The laissez-faire style attitude should not fit in these schools for principals and of instructors [6]. The students believed that through leadership style attitude, the coaches helped more in practice and learning than students of physical education. Moreover, the athletes had more positive feedback in connection with students of physical education [7]. Additionally, the relation of leadership style with communicational features has also been explored [8]-[14].

The fair play is a much-discussed issue. The moral values are of importance in sport and physical education, as this course often offers more opportunities for interactions and relations. It is proposed that physical education is an appropriate environment for initiation and education socio-moral issues [15]. Additionally, it is supported that exogenous (contextual - environmental) factors can be decisive determinants of moral behavior in sport [16]. It has been suggested that fair play is divided into three variables: fair play in competitions, fair play in total and in community [17]. Participants that distinguish from team spirit employ method equitable competitions [18]. Young basketball players with helping teachers can contribute in fair play [19]. The fair play contributed as a main and necessary role in the modern community, in physical education when teachers instructed in pupils and in the education of people [20]. Players of 12 - 14 years old believed that in team football on purpose foul involved the fair play for the moral field [21]. The fair play could help in decrease violence and in good relations among these that concern by sports [22]. People that participated in sport had higher results in relations goals, in knowledge-approximation and of performance-elusion goals [23]. Participants argued that fair play in physical education could play in techniques with regard to subjects' empathic content [24]. During mediations of students, the positive attitudes had increased, in contrast to negative attitudes that persist either low or reduced by way of interventions, the fair play concerned with sociable attitudes in lesson of physical education, in particular of football [25], while the role of communicational features in the 
framework of fairness has also been examined [26].

Machiavellianism is a term referring to a particular behavior pattern, involving manipulation of others into perfidy, wickedness, opportunism, and deceit [27]. Machiavellianists are expected to be ideologically neutral, to present restricted emotional involvement and to avoid commitments when it is favorable for them [28] [29]. It is identified four dimensions in Machiavellianism, distrust towards others, desire for power, desire for control and unethical manipulation [28]. Many analyses have supported that Machiavellian persons often follow dishonest and offensive ways to achieve their goals without being convinced by others themselves [30] [31]. Additionally, these persons tend to violate the rights of others for the sake of their personal interest [31]. Certain relations between Machiavellianism and subjects celebrities need to elucidate [32]. The Machiavellian teacher is expected to be characterized by self-efficacy, attitude of mind for appreciation, ingenuity, good behavior and high positions [33]. Machiavellianism is associated negatively with emotional intelligence [34]. Subsidiary psychopathy and the emotional intelligence and the Machiavellianism are of determinant relevance, when stimuli are controversial [35]. No differences were found between persons within the same group [36]. Casualties proved to have similar landmarks with self-expedience [37], while communicational dimensions have also been examined on the basis Machiavellianism [5] [38].

\subsection{Innovation of Study}

The interpretation of the relation of instructors' leadership style with phenomena of Machiavellianism and fairness perception in the school still remains a remarkable research challenge. The contribution of this research to a better understanding of this relationship is the expected academic added value. The chances of designing appropriate leadership patterns on the side of the teachers in order to control Machiavellianism and assure "fair play" among the students constitutes the practical added value, which is sought in the paper.

\section{Method}

\subsection{Participants and Procedures}

Participants in this study were 292 students (151 boys and 141 girls) aged $10-15$ years old. They originated from Volos, Trikala and Larissa regions, Greece. The participants were from the $5^{\text {th }}$ class of primary schools ( 65 students), $6^{\text {th }}$ class of primary schools (159 students), $1^{\text {st }}$ class of secondary schools (26 students), $2^{\text {nd }}$ class (32 students) and the $3^{\text {nd }}$ class of secondary schools (10 students), as presented in Table 1 . The students answered anonymously in questionnaires related

Table 1. Sample data.

\begin{tabular}{ccccccc}
\hline School & \multicolumn{2}{c}{ Primary } & \multicolumn{2}{c}{ Secondary } & Total \\
\hline Class & $5^{\text {th }}$ & $6^{\text {th }}$ & $1^{\text {st }}$ & $2^{\text {nd }}$ & $3^{\text {rd }}$ & 5 classes \\
Students number & 65 & 159 & 26 & 32 & 10 & 292 students \\
\hline
\end{tabular}


with instructors' leadership style (autocratic and democratic) and their self-perceived fair play-related behaviors (convention, respect to teammates, gamesmanship and cheating) and Machiavellianism. They answered in 10 - 15 minutes.

\subsection{Instruments}

The following instruments have been applied on the afore-mentioned sample of 292 students: a) A shorter version of the Leadership Scale for Sports (L.S.S.), [39], was used in order to measure perceived instructors' leadership style. This short version consisted of 6 items describing autocratic leadership style and 5 items describing democratic leadership style only two of the five dimensions were used. b) The version was used to assess students' fair play behaviors, based on the conceptualization of fair play [40], which included four subscales measuring two pro-social fair play behaviors: convention, respect to teammates and two anti-social fair play behaviors: gamesmanship and cheating. c) A version of the Machiavellianism Scale [29]) was used in order to measure students' Machiavellianism and the scale consisted of ten items. Participants were asked to respond to the items based on a 5-point Likert-type scale ranging from $1=$ never to $5=$ always.

\subsection{Data Analysis}

Data analysis was conducted with S.P.S.S. Cronbach's alpha test was used for checking the reliability and for detecting internal cohesion of variables. T-test was applied on Independent Samples Test in order to find significant differences between the participants' sexes. The one way ANOVA was used to examine the dependent variables. Pearson test was used for measuring the correlation of factors on questionnaires. Regression analysis was also used. Finally, Principal Component Analysis was implemented for suggesting a typology.

\section{Results}

Statistically significant differences were observed in students gender for convention $\left(\mathrm{t}_{(1,290)}=-3.70, \mathrm{p}<0.05\right)$, respect to teammates $\left(\mathrm{t}_{(1,290)}=-3.69, \mathrm{p}<0.05\right)$, gamesmanship $\left(\mathrm{t}_{(1,290)}=3.12, \mathrm{p}<0.05\right)$, cheating $\left(\mathrm{t}_{(1,290)}=3.45, \mathrm{p}<0.05\right)$, autocratic leadership style $\left(t_{(1,290)}=3.13, p<0.05\right)$, democratic leadership style $\left(t_{(1,290)}\right.$ $=-2.40, \mathrm{p}<0.05)$ and Machiavellianism $\left(\mathrm{t}_{(1,290)}=3.23, \mathrm{p}<0.05\right)$, as indicated in Table 2.

ANOVA's results supported that there were significant differences between students $5^{\text {th }}$ grade of primary schools, $6^{\text {th }}$ grade of primary schools, $1^{\text {st }}$ grade of secondary schools, $2^{\text {th }}$ grade of secondary schools and $3^{\text {th }}$ grade of secondary schools on the factors convention $\left(\mathrm{F}_{(4,287)}=4.55, \mathrm{p}<0.05\right)$, respect to teammates $\left(\mathrm{F}_{(4,287)}=4.51, \mathrm{p}<0.05\right)$, gamesmanship $\left(\mathrm{F}_{(4,287)}=5.86, \mathrm{p}<0.05\right)$, cheating $\left(\mathrm{F}_{(4,287)}\right.$ $=3.66, \mathrm{p}<0.05)$, autocratic leadership style $\left(\mathrm{F}_{(4,287)}=5.73, \mathrm{p}<0.05\right)$, democratic leadership style $\left(\mathrm{F}_{(4,287)}=5.05, \mathrm{p}<0.05\right)$ and Machiavellianism $\left(\mathrm{F}_{(4,287)}=4.87, \mathrm{p}<\right.$ 0.05), as shown in Table 3. 
Table 2. Students' gender comparison (data source: sampling in primary and secondary schools of Volos, Trikala and Larissa regions, Greece, 2017).

\begin{tabular}{cccccccc}
\hline Variables & Gender & $\mathrm{N}$ & Mean & $\mathrm{SD}$ & $\mathrm{t}$ & $\mathrm{df}$ & $\mathrm{p}$ \\
\hline \multirow{2}{*}{ Convention } & males & 151 & 2.30 & 1.13 & -3.70 & 290 & 0.00 \\
& females & 141 & 2.81 & 1.25 & & & \\
Respect & males & 151 & 2.31 & 1.15 & -3.69 & 290 & 0.00 \\
& females & 141 & 2.83 & 1.24 & & & \\
Gamesmanship & males & 151 & 3.29 & & & & \\
& females & 141 & 2.84 & 1.18 & 3.12 & 290 & 0.00 \\
Cheating & males & 151 & 3.50 & 1.05 & 3.45 & 290 & 0.00 \\
& females & 141 & 3.03 & 1.24 & & & \\
Autocratic & males & 151 & 3.35 & 1.10 & 3.13 & 290 & 0.00 \\
& females & 141 & 2.93 & 1.16 & & & \\
Democratic & males & 151 & 2.57 & 1.30 & & & \\
& females & 141 & 2.95 & 1.40 & -2.40 & 290 & 0.02 \\
\multirow{2}{*}{ Machiavellianism } & males & 151 & 3.30 & 0.95 & 3.23 & 290 & 0.00 \\
& females & 141 & 2.92 & 1.05 & & & \\
\hline
\end{tabular}

In addition, a correlation analysis was carried out, the effects that indicate in Table 4. From the results appear, that there was a negative significant relationship between autocratic and democratic leadership style $(r=-0.77)$, convention $(r=-0.75)$ and respect to teammates $(r=-0.74)$, while there was a positive significant relationship between autocratic and gamesmanship $(r=0.76)$, cheating $(r=0.73)$ and Machiavellianism $(r=0.68)$. Further down, Table 3 turns up the Cronbach's alpha, mean scores and standard deviations of the seven variables.

Additionally, run off regression analyze to autocratic leadership style and democratic leadership style with contribution of variables fair play (convention, respect to teammates, gamesmanship, cheating) and variable of Machiavellianism. The effects demonstrated that are statistic significant the autocratic leadership style with convention, respect to teammates, gamesmanship and cheating $\left(\mathrm{F}_{(4,287)}=116.89, \mathrm{p}<0.001\right)$ with an $\mathrm{R}^{2}$ of $62 \%$. Perceived autocratic leadership style explained $62 \%$ of the variance in convention $(\beta=-0.25, \mathrm{t}=-2.08, \mathrm{p}<0.05)$, explained $62 \%$ of the variance in gamesmanship $(\beta=0.34, \mathrm{t}=4.07, \mathrm{p}<0.001)$, $62 \%$ of the variance cheating $(\beta=0.16, \mathrm{t}=2.02, \mathrm{p}<0.05)$, when there were no differences between autocratic leadership style with respect to teammates $(62 \%$ prediction, $\beta=-0.07, \mathrm{t}=-0.60, \mathrm{p}=0.55)$. The results indicated that are statistic significant the autocratic leadership style with Machiavellianism $\left(\mathrm{F}_{(1,290)}=248.08\right.$, $\mathrm{p}<0.001)$ with an $\mathrm{R}^{2}$ of $46.1 \%$. Perceived autocratic leadership style explained $46.1 \%$ of the variance in Machiavellianism $(\beta=0.68, \mathrm{t}=15.75, \mathrm{p}<0.001)$. The effects demonstrated that are statistic significant the democratic leadership style with convention, respect to teammates, gamesmanship and cheating $\left(\mathrm{F}_{(4,287)}=\right.$ 204.51, $\mathrm{p}<0.001$ ) with an $\mathrm{R}^{2}$ of $74 \%$. Perceived democratic leadership style explained $74 \%$ of the variance in convention $(\beta=0.20, \mathrm{t}=2.06, \mathrm{p}<0.05)$, explained $74 \%$ of the variance in respect to teammates $(\beta=0.29, \mathrm{t}=2.91, \mathrm{p}<$ $0.001), 74 \%$ of the variance gamesmanship $(\beta=-0.49, \mathrm{t}=-7.05, \mathrm{p}<0.001)$, when 
there were no differences between democratic leadership style with cheating ( $74 \%$ prediction, $\beta=1.00, \mathrm{t}=1.52, \mathrm{p}=0.13$ ). The results indicated that are statistic significant the democratic leadership style with Machiavellianism $\left(\mathrm{F}_{(1,290)}=\right.$ 349.32 , $\mathrm{p}<0.001)$ with an $\mathrm{R}^{2}$ of $54.6 \%$. Perceived democratic leadership style explained $54.6 \%$ of the variance in Machiavellianism $(\beta=-0.74, \mathrm{t}=-18.69, \mathrm{p}<$ 0.001). The effects of the regression analyses are displayed in Table 5.

Table 3. Students classes comparison (data source: sampling in primary and secondary schools of Volos, Trikala and Larissa regions, Greece, 2017).

\begin{tabular}{|c|c|c|c|c|c|c|}
\hline Variables & Schools classes & $\mathrm{N}$ & Mean & SD & $\mathrm{F}$ & $\mathrm{p}$ \\
\hline \multirow{5}{*}{ Convention } & $5^{\text {th }}$ grade & 65 & 2.11 & 0.13 & \multirow{2}{*}{4.55} & \multirow{2}{*}{0.001} \\
\hline & $6^{\text {th }}$ grade & 159 & 2.58 & 1.24 & & \\
\hline & $1^{\text {st }}$ grade & 26 & 3.03 & 1.21 & \multirow{8}{*}{4.51} & \multirow{8}{*}{0.001} \\
\hline & $2^{\text {st }}$ grade & 32 & 2.59 & 1.13 & & \\
\hline & $3^{\text {st }}$ grade & 10 & 3.40 & 1.28 & & \\
\hline \multirow{5}{*}{ Respect } & $5^{\text {th }}$ grade & 65 & 2.09 & 1.03 & & \\
\hline & $6^{\text {th }}$ grade & 159 & 2.61 & 1.23 & & \\
\hline & $1^{\text {st }}$ grade & 26 & 2.96 & 1.22 & & \\
\hline & 2 st grade & 32 & 2.72 & 1.22 & & \\
\hline & 3 st grade & 10 & 3.32 & 1.42 & & \\
\hline \multirow{5}{*}{ Gamesmanship } & $5^{\text {th }}$ grade & 65 & 3.66 & 1.05 & \multirow{5}{*}{5.86} & \multirow{5}{*}{0.000} \\
\hline & $6^{\text {th }}$ grade & 159 & 3.00 & 1.27 & & \\
\hline & $1^{\text {st }}$ grade & 26 & 2.54 & 1.19 & & \\
\hline & $2^{\text {nd }}$ grade & 32 & 2.86 & 1.20 & & \\
\hline & $3^{\text {rd }}$ grade & 10 & 2.57 & 1.31 & & \\
\hline \multirow{5}{*}{ Cheating } & $5^{\text {th }}$ grade & 65 & 3.70 & 0.96 & \multirow{5}{*}{3.66} & \multirow{5}{*}{0.006} \\
\hline & $6^{\text {th }}$ grade & 159 & 3.20 & 1.21 & & \\
\hline & $1^{\text {st }}$ grade & 26 & 3.01 & 1.22 & & \\
\hline & $2^{\text {nd }}$ grade & 32 & 3.24 & 1.06 & & \\
\hline & $3^{\text {rd }}$ grade & 10 & 2.57 & 1.31 & & \\
\hline \multirow{5}{*}{ Autocratic } & $5^{\text {th }}$ grade & 65 & 3.62 & 0.99 & \multirow{5}{*}{5.73} & \multirow{5}{*}{0.000} \\
\hline & $6^{\text {th }}$ grade & 159 & 3.12 & 1.13 & & \\
\hline & $1^{\text {st }}$ grade & 26 & 2.55 & 1.21 & & \\
\hline & $2^{\text {nd }}$ grade & 32 & 2.99 & 1.18 & & \\
\hline & $3^{\text {rd }}$ grade & 10 & 2.57 & 1.11 & & \\
\hline \multirow{5}{*}{ Democratic } & $5^{\text {th }}$ grade & 65 & 2.17 & 1.18 & \multirow{5}{*}{5.05} & \multirow{5}{*}{0.001} \\
\hline & $6^{\text {th }}$ grade & 159 & 2.83 & 1.36 & & \\
\hline & $1^{\text {st }}$ grade & 26 & 3.25 & 1.45 & & \\
\hline & $2^{\text {nd }}$ grade & 32 & 2.89 & 1.28 & & \\
\hline & $3^{\text {rd }}$ grade & 10 & 3.50 & 1.34 & & \\
\hline \multirow{5}{*}{ Machiavellianism } & $5^{\text {th }}$ grade & 65 & 3.47 & 0.81 & \multirow{5}{*}{4.87} & \multirow{5}{*}{0.001} \\
\hline & $6^{\text {th }}$ grade & 159 & 3.13 & 1.02 & & \\
\hline & $1^{\text {st }}$ grade & 26 & 2.66 & 1.02 & & \\
\hline & $2^{\text {nd }}$ grade & 32 & 2.96 & 1.14 & & \\
\hline & $3^{\text {rd }}$ grade & 10 & 2.43 & 1.00 & & \\
\hline
\end{tabular}


Table 4. Reliabilities, Means, Standard Deviations and Pearson Correlations among seven variables (data source: sampling in primary and secondary schools of Volos, Trikala and Larissa regions, Greece, 2017).

\begin{tabular}{|c|c|c|c|c|c|c|c|c|c|c|}
\hline & $\alpha$ & M & SD & 1 & 2 & 3 & 4 & 5 & 6 & 7 \\
\hline 1) Autocratic & 0.94 & 3.15 & 1.14 & 1.00 & & & & & & \\
\hline 2) Democratic & 0.96 & 2.75 & 1.36 & $-0.77^{\star *}$ & 1.00 & & & & & \\
\hline 3) Convention & 0.88 & 2.55 & 1.22 & $-0.75^{\star *}$ & $0.82^{\star *}$ & 1.00 & & & & \\
\hline 4) Respect & 0.88 & 2.56 & 1.22 & $-0.74^{\star *}$ & $0.82^{\star *}$ & $0.95^{\star *}$ & 1.00 & & & \\
\hline 5) Gamesmanship & 0.91 & 3.07 & 1.25 & $0.76^{* *}$ & $-0.83^{\star \star}$ & $-0.87^{\star \star}$ & $-0.87^{\star *}$ & 1.00 & & \\
\hline 6) Cheating & 0.87 & 3.27 & 1.17 & $0.73^{\star *}$ & $-0.74^{* *}$ & $-0.86^{\star *}$ & $-0.85^{\star *}$ & $0.85^{\star *}$ & 1.00 & \\
\hline 7) Machiavellianism & 0.95 & 3.12 & 1.01 & $0.68^{* *}$ & $-0.74^{\star *}$ & $-0.81^{\star *}$ & $-0.80^{\star *}$ & $0.81^{* *}$ & $0.85^{* *}$ & 1.00 \\
\hline
\end{tabular}

${ }^{* *} \mathrm{p}<0.001,{ }^{*} \mathrm{p}<0.05, \alpha=$ Cronbach's alpha, $\mathrm{M}=$ Means, $\mathrm{SD}=$ Standard Deviations.

Table 5. Regression analysis results according to autocratic and democratic leadership style (data source: sampling in primary and secondary schools of Volos, Trikala and Larissa regions, Greece, 2017).

\begin{tabular}{|c|c|c|c|c|c|c|}
\hline & Autocratic & B & $95 \%$ CI B & SE & $\beta$ & $\mathrm{t}$ \\
\hline Convention & & -0.24 & $-0.46,-0.01$ & 0.11 & -0.25 & $-2.08^{\star}$ \\
\hline Gamesmanship & & 0.31 & $0.16,0.46$ & 0.08 & 0.34 & $4.07^{\star \star}$ \\
\hline Cheating & & 0.16 & $0.00,0.31$ & 0.08 & 0.16 & $2.02^{*}$ \\
\hline \multirow[t]{2}{*}{ Machiavellianism } & & 0.77 & $0.67,0.86$ & 0.05 & 0.68 & $15.75^{\star *}$ \\
\hline & Democratic & $\mathrm{B}$ & $95 \%$ CI B & SE & $\beta$ & $\mathrm{t}$ \\
\hline Convention & & 0.23 & $0.01,0.45$ & 0.11 & 0.20 & $2.06^{*}$ \\
\hline Respect & & 0.32 & $0.10,0.53$ & 0.11 & 0.29 & $2.91^{\star *}$ \\
\hline Cheating & & 0.11 & $-0.03,0.26$ & 0.08 & 1.00 & 1.52 \\
\hline Machiavellianism & & -0.99 & $-1.09,-0.88$ & 0.05 & -0.74 & $-18.69^{\star *}$ \\
\hline
\end{tabular}

${ }^{* *} \mathrm{p}<0.001,{ }^{*} \mathrm{p}<0.05$.

In Table 6, three types of students' perceptions appear referring to their own behavior as well as the behavior of their instructors: the "bad and controlled student", the "respectful and weak student" and the "typical autocratic instructor".

Concisely, gender-specific differences were observed regarding the convention, respect to teammates, gamesmanship, cheating, autocratic leadership style, democratic leadership style and Machiavellianism. Age-specific differences were observed concerning convention, respect to teammates, gamesmanship, cheating, autocratic leadership style, democratic leadership style and Machiavellianism as well. A negative significant relationship appeared between autocratic and democratic leadership style, convention and respect to teammates, while a positive one appeared between autocratic and gamesmanship, cheating and Machiavellianism. Autocratic leadership style is predictable by convention, respect to 
Table 6. Mixed typology of students' perceptions (data source: sampling in primary and secondary schools of Volos, Trikala and Larissa regions, Greece, 2017).

\begin{tabular}{|c|c|c|c|c|c|c|}
\hline & & & & $\begin{array}{c}\text { "The bad } \\
\text { and controlled } \\
\text { student" }\end{array}$ & $\begin{array}{c}\text { "The } \\
\text { respectful } \\
\text { weak student" }\end{array}$ & $\begin{array}{l}\text { "The typical } \\
\text { autocratic } \\
\text { instructor" }\end{array}$ \\
\hline \multirow{21}{*}{$\begin{array}{l}\text { Students' } \\
\text { self-perceived } \\
\text { behavior }\end{array}$} & \multirow[t]{11}{*}{$\begin{array}{l}\text { Fair play-relevant } \\
\text { behaviors }\end{array}$} & Convent & Congratulating opponents & -0.802 & 0.414 & 0.168 \\
\hline & & \multirow[t]{2}{*}{ Respect } & Supporting teammates & -0.802 & 0.419 & 0.143 \\
\hline & & & Congratulating teammates' effort & -0.806 & 0.367 & 0.186 \\
\hline & & \multirow[t]{4}{*}{ Gamesmanship } & Upsetting opponents & 0.805 & -0.356 & 0.032 \\
\hline & & & Disturbing opponents & 0.791 & 0.305 & -0.173 \\
\hline & & & Speaking badly to opponents & 0.867 & -0.278 & -0.026 \\
\hline & & & Irritating opponents & 0.829 & -0.302 & 0.002 \\
\hline & & \multirow[t]{4}{*}{ Cheating } & Cheating & 0.760 & 0.472 & -0.157 \\
\hline & & & Willing to cheat & 0.755 & 0.357 & -0.109 \\
\hline & & & Cheating to win & 0.860 & -0.293 & 0.020 \\
\hline & & & Cheating safely & 0.756 & 0.379 & -0.118 \\
\hline & \multirow{10}{*}{\multicolumn{2}{|c|}{ Machiavellian behavior }} & Deceiving for own benefit & 0.755 & 0.149 & 0.063 \\
\hline & & & Deceiving to get whatever desired & 0.832 & 0.174 & 0.104 \\
\hline & & & Behaving with cunning & 0.837 & 0.182 & 0.188 \\
\hline & & & Stepping on others & 0.784 & 0.215 & 0.135 \\
\hline & & & Enjoying intrigue & 0.775 & 0.237 & 0.229 \\
\hline & & & Acting for own benefit & 0.737 & 0.225 & 0.116 \\
\hline & & & Winning important & 0.816 & 0.202 & 0.180 \\
\hline & & & Being merciless & 0.784 & 0.219 & 0.202 \\
\hline & & & Being modest and honest & 0.527 & 0.182 & 0.284 \\
\hline & & & Being potent & 0.835 & 0.185 & 0.201 \\
\hline \multirow{11}{*}{$\begin{array}{l}\text { Instructors' } \\
\text { behavior as } \\
\text { perceived by } \\
\text { students }\end{array}$} & \multirow[t]{11}{*}{ Leadership style } & \multirow[t]{6}{*}{ Autocratic style } & Deciding by himself & 0.737 & 0.020 & 0.286 \\
\hline & & & Choosing activities by himself & 0.712 & -0.057 & 0.185 \\
\hline & & & Not considering students & 0.741 & -0.163 & 0.127 \\
\hline & & & Planning by himself & 0.759 & -0.059 & 0.320 \\
\hline & & & Not clarifying & 0.723 & -0.216 & 0.175 \\
\hline & & & Keeping distance & 0.797 & -0.287 & 0.068 \\
\hline & & \multirow{5}{*}{$\begin{array}{l}\text { Democratic } \\
\text { style }\end{array}$} & Treating mistakes graciously & -0.841 & 0.309 & 0.120 \\
\hline & & & Letting students set their goals & -0.819 & 0.262 & 0.163 \\
\hline & & & Letting students try things & -0.851 & 0.156 & 0.100 \\
\hline & & & Letting students at their own pace & -0.843 & 0.236 & 0.043 \\
\hline & & & $\begin{array}{l}\text { Allowing students suggest ways of } \\
\text { practicing }\end{array}$ & -0.842 & 0.227 & 0.066 \\
\hline
\end{tabular}

Extraction Method: Principal Component Analysis, 4 components extracted. 
teammates, gamesmanship and cheating, Machiavellianism, while democratic leadership style by convention, respect to teammates, gamesmanship and cheating. Three types of students' perceptions appeared regarding their own as well as their instructors' behavior: "bad and controlled student", "respectful and weak student" and "typical autocratic instructor".

\section{Discussion}

The aim of this study was fourfold: a) to explore differences between the sexes and among classes regarding leadership style, fair play and Machiavellianism, b) to investigate the relationship between physical education instructors' leadership style as perceived by students and students' fair play and Machiavellianism, c) to examine the influence of instructor leadership style on student fair play and Machiavellianism and d) to suggest instructors' and students' typology. The results of the study indicated that statistically significant differences were observed in perceived instructors' leadership style (more "autocratic" style toward male students and "democratic" toward female), antisocial behaviors by male students and pro-social behaviors by the female ones and Machiavellianism by male students. It has been found that the students of the $5^{\text {th }}$ class of primary school are especially susceptible to see autocratic leadership style on their instructors and to perceive more gamesmanship, cheating and Machiavellianism on themselves. However, the students of the $3^{\text {rd }}$ class of secondary school tend to see more democratic leadership style on their instructors and to believe that they present more convention and respectfulness to their teammates. Also, perceived instructors' autocratic leadership style was negatively related to students' prosocial fair play behaviors, while was positively related to students' antisocial fair play behaviors and Machiavellian tactics. The results of regression analysis revealed that perceived instructors' autocratic leadership style could significantly predict the variables of students' fair play behaviors (convention, gamesmanship, cheating) and Machiavellianism, while democratic leadership style could significantly predict the variables of students' fair play behaviors (convention, respect to teammates, gamesmanship) and Machiavellianism. Three particular profiles have been proposed: the "bad and controlled student", the "respectful and weak student" and the "typical autocratic instructor".

In the present study, male students seem to regard their instructors as more autocratic than female ones. This is in accordance with previous research which supported that educators were more aggressive to boys than to girls [8] [41]. Consequently, male students regard their instructors as more autocratic, while they perceive themselves to present more anti-social fair play-related behaviors and more Machiavellian tactics than female ones. These results are also compatible with findings of other studies where instructors proved to be more aggressive to male students due to their disobedience and indiscipline [42]. Moreover, the present findings are in accordance with [9] which supported that autocratic leadership style mainly appeared in male rather than in female. It was presented 
that male students had a predisposition that appraises more the Machiavellianism in connection with female students as and in our study [43]. Female students had higher scores than male students on deceiving and in impression management that have relation with Machiavellianism of median age 20 years old [44]. The self-deception of the male students was more intensive than of the female ones [44]. Thus, it is likely that autocratic behavior of instructors is a main reason for the facts that male students show more intensive Machiavellianism. However, autocratic as well as aggressive attitude is quite dissuasive for all trainees, independent of gender [45].

In the present study, the students of the $5^{\text {th }}$ class of primary school perceive more autocratic leadership style on their instructors and more gamesmanship, cheating and Machiavellianism on themselves, while the students of the $3^{\text {rd }}$ class of secondary school ascribed more democratic leadership style to their instructors and more convention and respectfulness to themselves. This can be attributed to a possible more egoism which is immanent in the students of an earlier age. Results appeared in democratic and autocratic style after having discovered significant disparities between the $5^{\text {th }}$ and the $6^{\text {th }}$ grade of elementary school [26]. Trainees between 14 and 17 years old and their instructors showed their preferences to low autocratic leadership style and high democratic leadership style [46]. Especially, the two last classes of primary schools presented a high score in Machiavellianism [47].

The results of this study seem to be consistent with previous research, indicating that leadership style contributed to the improvement of skills and of relations between trainees and instructors [48], as in present study was showed that instructors' democratic leadership style was positively correlated with convention and respect to teammates. It is indicated that perceived instructors' autocratic leadership style affects not only student fair play behaviors but also their Machiavellianism, which is in accordance with the content of previous research [30] [31]. Moreover, it is supported that perceived instructors' democratic leadership style affects negatively students' Machiavellianism, which is consistent with previous research [49] [50] [51]. Instructors' personality was found to play a major role in the relations with their students and to influence their emotions, behavior and attitudes [52] [53] [54]. Instructor's autocratic leadership style proved to be a quite important predictor of the students' fair play behaviors and Machiavellianism, which is consistent with previous findings indicating that instructors' aggressive behavior is in negative relation with convention and respectfulness, while it is positively related with cheating and gamesmanship [26] [38]. Simultaneously, it is pointed out that there is a relationship between moral judgments and Machiavellianism [55] [56] [57].

In the present study, the three types can be understood as follows: The first type is the "bad and controlled student". Students who accept that they are susceptible to gamesmanship, cheating and Machiavellianism tend to see their instructors as fully autocratic. This is understandable as such "bad" students are 
often controlled by their instructor. As a result of this, they find him too strict and "autocratic" to them. Inversely, if an instructor is really too strict and demands from them high performance in physical education, then the students are thereby pressed to use gamesmanship, cheating and Machiavellian tactics. The second type is quite compatible with the everyday experience. This is the type of "respectful and weak" student. Students who are susceptible to convent and respectfulness to others, only occasionally may present gamesmanship and cheating behavior. Thus, the instructors have no particular reason to draw their attention to them or to control them strictly. Therefore, they regard their instructors as "democratic". They seem to behave "democratically" to them as a reward for their conscientious behavior. Finally, the "autocratic instructor" seems to be a quiet "typical" instructor's profile in the perception of the students, as it appears independently of any self-perceptions of students ("cheaters" or not etc). Thus, the "autocratic" style is apparently established in the behavioral perception patterns of the students as an immanent feature of being an instructor. Such typologies have been proposed in previous research [58]-[71].

It has been supported that the negative atmosphere at home and the loneliness seems to be in negative relation with Machiavellianism [72]. Machiavellianism appearing in childhood can also be interpreted as a reaction to authoritarianism [73]. On the other hand, in adults it seems to be correlated with hostile attitudes [74] and with aggressiveness [37] [75] [76]. It is argued that moral elements were in negative relation with Machiavellianism [77].

A normative comment derived from the empirical findings is that physical education instructors should avoid autocratic behavior, as Machiavellianism seems to be related with unfairness, aggressiveness, antisocial fair play behaviors and superficial obedience. On the contrary, instructors should present democratic behavior, which is conducive to a supportive classroom climate and to a greater self-confidence of students. Future research can focus on the influence of more and more detailed variables on Machiavellianism as well as on applying social network analysis in combination with socio-personal features.

\section{Conclusion}

Differences between the sexes and among classes regarding leadership style, fair play and Machiavellianism were discussed. The relationship between physical education instructors' leadership style as perceived by students and students' fair play and Machiavellianism was explored. The influence of instructor leadership style on student fair play and Machiavellianism was examined. Finally, an instructors' and students' typology was suggested. The instructors' leadership style was more "autocratic" style toward male students and "democratic" toward female ones. Antisocial behaviors by male students and pro-social behaviors by the female ones and Machiavellianism by male students were observed. The 5th class students in primary school are susceptible to perceive autocratic leadership style on their instructors and more gamesmanship, cheating and Machiavellianism on 
themselves. The 3rd class students in secondary school tend to perceive more democratic leadership style on their instructors and more convention and respectfulness on themselves. The perceived instructors' leadership style is negatively related to students' prosocial fair play behaviour and positively related to students' antisocial fair play behavior and Machiavellianism. Three particular profiles have been proposed: the "bad and controlled student", the "respectful and weak student" and the "typical autocratic instructor". Challenges for future research can consist in exploring further variables influencing the perception and behavior such as family situation. Network analysis can also be used for detecting perceptions of leadership styles, pro- or antisocial behaviors and Machiavellianism.

\section{Conflicts of Interest}

The authors declare no conflicts of interest regarding the publication of this paper.

\section{References}

[1] Nanjundeswaraswamy, T.S. and Swamy, D.R. (2014) Leadership Styles. Advances in Management, 7, 57-62.

[2] Iqbal, N., Anwar, S. and Haider, N. (2015) Effect of Leadership Style on Employee Performance. Arabian Journal of Business and Management Review, 5, 1-6.

[3] Jerome, I. (2018) An Investigation on the Nexus between Leadership Style and Job Satisfaction of Library Staff in Private University Libraries South-West, Nigeria. $\mathrm{Li}$ brary Philosophy and Practice (E-Journal). 1677.

http://www.emeraldinsight.com/doi/abs/10.1108/LODJ-11-2011-0114

[4] Turman, P.D. (2001) Situational Coaching Styles: The Impact of Success and Athlete Maturity Level on Coaches' Leadership Styles over Time. Small Group Research, 32, 576-594. https://doi.org/10.1177/104649640103200504

[5] Bekiari, A. (2016) Insights into Instructors' Verbal Aggressiveness and Students' Machiavellianism through Leadership Style and Motivational Climate. European Scientific Journal, 12, 90-110. https://doi.org/10.19044/esj.2016.v12n25p90

[6] Adeyemi, T.O. (2010) Principals' Leadership Styles and Teachers' Job Performance in Senior Secondary Schools in Ondo State, Nigeria. Journal of Education Administration and Policy Studies, 2, 83-91.

[7] Kwon, H.H., Pyun, D. and Kim, M. (2010) Perceived Leadership Behavior of Physical Education Teacher-Coaches: When They Teach vs. When They Coach. Journal of Teaching in Physical Education, 29, 131-145. https://doi.org/10.1123/jtpe.29.2.131

[8] Bekiari, A. (2014) Verbal Aggressiveness and Leadership Style of Sports Instructors and their Relationship with Athletes' Intrinsic Motivation. Creative Education, 5, 114-121. https://doi.org/10.4236/ce.2014.52018

[9] Bekiari, A. and Ntakou, V. (2018) Insights to Argumentativeness in Relation to Leadership Style and Job Satisfaction: Using Employees' Sport Organizations as an Illustration. Open Journal of Leadership, 7, 1-18. https://doi.org/10.4236/ojl.2018.71001

[10] Bekiari, A. and Balla, K. (2017) Instructors and Students Relations: Argumentative- 
ness, Leadership and Goal Orientations. Open Journal of Social Sciences, 5, 128-143. https://doi.org/10.4236/jss.2017.57009

[11] Theoharis, D., Bekiari, A. and Koustelios, A. (2017) Exploration of Determinants of Verbal Aggressiveness and Leadership through Network Analysis and Conventional Statistics. Using School Class as an Illustration. Sociology Mind, 7, 27-43. http://dx.doi.org/10.4236/sm.2017.72003

[12] Theoharis, D. and Bekiari, A. (2016) Social Networks Analysis of Centrality: Case Study in Leadership Networks. Proceedings of the 33rd Congress Greek Mathematical Society (with International Participation), Chania, 4-6 November 2016, 250-260.

[13] Theoharis, D. and Bekiari, A. (2017) Cumulative Hierarchy Analysis (Katz Centrality) on Leadership Networks of Learning Communities. Proceedings of the $9^{\text {th }}$ International Congress Mathematical Society, Thessaloniki, 17-19 March 2017, 285-297.

[14] Theoharis, D. and Bekiari, A. (2017) Structural Analysis of Leadership in School Class Networks. Proceedings of the 34th Congress Greek Mathematical Society, Lefkada, 271-279.

[15] Shields, D.L.L. and Bredemeier, B.J.L. (1995) Character Development and Physical Activity. Human Kinetics Publishers, Champaign, IL, England.

[16] Vallerand, R.J., Brière, N.M., Blanchard, C. and Provencher, P. (1997) Development and Validation of the Multidimensional Sportspersonship Orientations Scale. Journal of Sport \& Exercise Psychology, 19, 197-206.

https://doi.org/10.1123/jsep.19.2.197

[17] Popescu, V. and Masari, G.A. (2011) Comparative Analysis of Athletes' Fair Play Attitude According to Specific Variables Conditioned by Sports Training and Competition. Procedia-Social and Behavioral Sciences, 12, 24-29. https://doi.org/10.1016/j.sbspro.2011.02.006

[18] Sullivan, C.F. (2011) Gender Verification and Gender Policies in Elite Sport: Eligibility and "Fair Play". Journal of Sport and Social Issues, 35, 400-419. https://doi.org/10.1177/0193723511426293

[19] Vila, G.O., González, J.D., Martín, J.F., Guerra, J.G.F., Martín, P.J.J., Sánchez, C.J., Robles, M.A. and Miñano, M.J.C. (2016) Moral Development in Sports at School age: Towards a Fair Play Behaviours Typology Expressed in the White Card (Tarjeta Blanca) Programme. Movement \& Sport Sciences-Science \& Motricité, 91, 21-29. https://doi.org/10.1051/sm/2015007

[20] Miura, Y. (2015) Fair Play in the Physical Education Curriculum. LASE Journal of Sport Science, 6, 77-91. https://doi.org/10.1515/ljss-2016-0044

[21] Pilz, G.A. (1995) Performance Sport: Education in Fair Play? (Some Empirical and Theoretical Remarks). International Review for the Sociology of Sport, 30, 391-418. https://doi.org/10.1177/101269029503000310

[22] Göral, M. (2008) Violence and Fair Play in Sport. Pakistan Journal of Social Sciences, 5, 502-513.

[23] Fernández-Río, J., Méndez-Giménez, A., Cecchini, J.A. and González de Mesa, C. (2012) Achievement Goals and Social Goals' Influence on Physical Education Students' Fair Play. Revista de Psicodidáctica, 17, 73-91.

[24] Sezen-Balcikanli, G. (2009) Fair Play and Empathy: A Research Study with Student Teachers. Journal of US, 6, 79-84.

[25] Vidoni, C. and Ulman, J.D. (2010) Fair Play Instruction during Middle School Physical Education: A Systematic Replication. Journal of Behavioral Health and Medicine, 1, 127-136. https://doi.org/10.1037/h0100546 
[26] Bekiari, A. (2017) Exploring Relations between Instructors' Verbal Aggressiveness and Argumentativeness and Students' Fair Play Behaviours and Machiavellianism. International Journal of Physical Education, 54, 26-39.

[27] Walter, H.L., Anderson, C.M. and Martin, M.M. (2005) How Subortinates' Machiavellianism and Motives Relate to Satisfaction with Superiors. Communication Quarterly, 53, 57-70.

[28] Dahling, J.J., Whitaker, B.G. and Levy, P.E. (2009) The Development and Validation of a New Machiavellianism Scale. Journal of Management, 35, 219-257. https://doi.org/10.1177/0149206308318618

[29] Mudrack, P.E. and Mason, E.S. (1995) More on the Acceptability of Workplace Behaviors of a Dubious Ethical Nature. Psychological Reports, 76, 639-648. https://doi.org/10.2466/pr0.1995.76.2.639

[30] Christie, R. and Geis, F. (1970) Studies in Machiavellianism. Academic Press, New York.

[31] Zagenczyk, T.J., Restubog, S.L.D., Kiewitz, C., Kiazad, K. and Tang, R.L. (2014) Psychological Contracts as a Mediator between Machiavellianism and Employee Citizenship and Deviant Behaviors. Journal of Management, 40, 1098-1122. https://doi.org/10.1177/0149206311415420

[32] Vleeming, R.G. (1979) Machiavellianism: A Preliminary Review. Psychological Reports, 44, 295-310. https://doi.org/10.2466/pr0.1979.44.1.295

[33] Bańka, A. and Orłowski, K. (2012) The Structure of the Teacher Machiavellianism Model in Social Interactions in a School Environment. Polish Psychological Bulletin, 43, 215-222. https://doi.org/10.2478/v10059-012-0024-3

[34] Pilch, I. (2008) Machiavellianism, Emotional Intelligence and Social Competence: Are Machiavellians Interpersonally Skilled? Polish Psychological Bulletin, 39, 158-164. https://doi.org/10.2478/v10059-008-0017-4

[35] Ali, F., Amorim, I.S. and Chamorro-Premuzic, T. (2009) Empathy Deficits and Trait Emotional Intelligence in Psychopathy and Machiavellianism. Personality and Individual Differences, 47, 758-762. https://doi.org/10.1016/j.paid.2009.06.016

[36] Dhormare, A.R. (2016) Machiavellianism and Locus of Control among Individual and Team Game Players. Epitome Journals, 2, 145-153.

[37] Andreou, E. (2004) Bully/Victim Problems and Their Association with Machiavellianism and Self-Efficacy in Greek Primary School Children. British Journal of Educational Psychology, 74, 297-309.

[38] Bekiari, A. (2017) Verbally Aggressive Instructors and Machiavellian Students: Is the Socio-Communicative Style an Over-Bridging? Psychology, 8, 1437-1454. https://doi.org/10.4236/psych.2017.810095

[39] Chelladurai, P. and Saleh, S. D. (1980) Dimensions of Leader Behavior in Sports: Development of a Leadership Scale. Journal of Sport Psychology, 2, 34-45. https://doi.org/10.1123/jsp.2.1.34

[40] Schneider, A. and Butcher, R. (2001) Ethics, Sport, and Boxing. Ethics in Sport, 357-369.

[41] Bekiari, A. and Hasanagas, N. (2015) Verbal Aggressiveness Exploration through Complete Social Network Analysis: Using Physical Education Students' Class as an Illustration. International Journal of Social Science Studies, 3, 30-49. https://doi.org/10.11114/ijsss.v3i3.729

[42] Bekiari, A. and Petanidis, D. (2016) Exploring Teachers' Verbal Aggressiveness through Interpersonal Attraction and Students' Intrinsic Motivation. Open Journal 
of Social Sciences, 4, 72-85. https://doi.org/10.4236/jss.2016.412007

[43] Bekiari, A. and Spanou, K. (2018) Machiavellianism in Universities: Perceiving Exploitation in Student Networks. Social Networking, 7, 19-31.

https://doi.org/10.4236/sn.2018.71002

[44] Hren, D., Vujaklija, A., Ivanišević, R., Knežević, J., Marušić, M. and Marušić, A. (2006) Students' Moral Reasoning, Machiavellianism and Socially Desirable Responding: Implications for Teaching Ethics and Research Integrity. Medical Education, 40, 269-277.

[45] Gorham, J. and Christophel, D.M. (1992) Students' Perceptions of Teacher Behaviors as Motivating and Demotivating Factors in College Classes. Communication Quarterly, 40, 239-252.

[46] Syrmpas, I. and Bekiari, A. (2018) Differences between Leadership Style and Verbal Aggressiveness Profile of Coaches and the Satisfaction and Goal Orientation of Young Athletes. Journal of Physical Education and Sport, 18, 1008-1015.

[47] McGuire, D. and Hutchings, K. (2006) A Machiavellian Analysis of Organizational Change. Journal of Organizational Change Management, 19, 192-209. https://doi.org/10.1108/09534810610648906

[48] Asadi, N. (2013) Comparison Satisfaction in Athletes of Leadership Styles in the Sport of Karate. International Research Journal of Applied and Basic Sciences, 4, 3888-3891.

[49] Láng, A. and Birkás, B. (2015) Machiavellianism and Parental Attachment in Adolescence: Effect of the Relationship with Same-Sex Parents. Sage Open, 5, 1-7.

[50] Olson, D.H. (2000) Circumplex Model of Marital and Family Systems. Journal of Family Therapy, 22, 144-167.

[51] Ryumshina, L.I. (2013) Traits of the Self-Actualized Personality in the Modern Russian Politicians. Procedia-Social and Behavioral Sciences, 86, 396-401. https://doi.org/10.1016/j.sbspro.2013.08.586

[52] Horn, R. (2002) Coupled Movements in Voltage-Gated Ion Channels. Journal of General Physiology, 120, 449-453. https://doi.org/10.1085/jgp.20028658

[53] Infante, D.A. and Rancer, A.S. (1996) Argumentativeness and Verbal Aggressiveness: A Review of Recent Theory and Research. Annals of the International Communication Association, 19, 319-352.

[54] Rancer, A.S. and Avtgis, T.A. (2014) Argumentative and Aggressive Communication: Theory, Research, and Application. 2nd Edition, Peter Lang, New York.

[55] Mudrack, P.E., Bloodgood, J.M. and Turnley, W.H. (2012) Some Ethical Implications of Individual Competitiveness. Journal of Business Ethics, 108, 347-359. https://doi.org/10.1007/s10551-011-1094-4

[56] Pan, Y. and Sparks, J.R. (2012) Predictors, Consequence, and Measurement of Ethical Judgments: Review and Meta-Analysis. Journal of Business Research, 65, 84-91. https://doi.org/10.1016/j.jbusres.2011.02.002

[57] Shafer, W.E. and Simmons, R.S. (2008) Social Responsibility, Machiavellianism and Tax Avoidance: A Study of Hong Kong Tax Professionals. Accounting, Auditing \& Accountability, 21, 695-720. https://doi.org/10.1108/09513570810872978

[58] Bekiari, A., Deliligka, S. and Hasanagas, N. (2017) Analysing Networks of Verbal Aggressiveness and Motivation. Psychology, 8, 495-515.

https://doi.org/10.4236/psych.2017.83031

[59] Bekiari, A., Deliligka, S. and Koustelios, A. (2017) Examining Relations of Aggressive Communication in Social Networks. Social Networking, 6, 38-52. 
https://doi.org/10.4236/sn.2017.61003

[60] Bekiari, A. and Hasanagas, N. (2016) Suggesting Indicators of Superficiality and Purity in Verbal Aggressiveness. An Application in Adult Education Class Networks of Prisoners. Open Journal of Social Sciences, 4, 279-292. https://doi.org/10.4236/jss.2016.43035

[61] Bekiari, A., Hasanagas, N., Theoharis, D., Kefalas, I. and Vasilou, A. (2015) The Role of Mathematical Object and the Educational Environment to Students' Interpersonal Relationships: An Application of Full Social Network Analysis. Proceedings of the 32 nd Congress Greek Mathematical Society (with International Participation), Kastoria, 28 October-1 November 2015, 799-812.

[62] Bekiari, A., Nikolaidou, Z. and Hasanagas, N. (2017) Typology of Motivation and Aggression on the Basis of Social Network Variables: Examples of Complementary and Nested Behavioral Types through Conventional Statistics. Social Networking, 6 , 135-147. https://doi.org/10.4236/sn.2017.62008

[63] Bekiari, A. and Pachi, V. (2017) Insights into Bullying and Verbal Aggressiveness through Social Network Analysis. Journal of Computer and Communications, 5, 79-101. https://doi.org/10.4236/jcc.2017.59006

[64] Bekiari, A., Pachi, V. and Hasanagas, N. (2017) Investigating Bullying Determinants and Typologies with Social Network Analysis. Journal of Computer and Communications, 5, 11-27. https://doi.org/10.4236/jcc.2017.57002

[65] Bekiari, A. and Spyropoulou, S. (2016) Exploration of Verbal Aggressiveness and Interpersonal Attraction through Social Network Analysis: Using University Physical Education Class as an Illustration. Open Journal of Social Sciences, 4, 145-155. https://doi.org/10.4236/jss.2016.46016

[66] Hasanagas, N. and Bekiari, A. (2015) Depicting Determinants and Effects of Intimacy and Verbal Aggressiveness Target through Social Network Analysis. Sociology Mind, 5, 162-175. https://doi.org/10.4236/sm.2015.53015

[67] Hasanagas, N. and Bekiari, A. (2017) An Exploration of the Relation between Hunting and Aggressiveness: Using Inmates Networks at Prison Secondary School as an Illustration. Social Networking, 6, 19-37. https://doi.org/10.4236/sn.2017.61002

[68] Hasanagas, N., Bekiari, A. and Vasilos, P. (2017) Friendliness to Animals and Verbal Aggressiveness to People: Using Prison Inmates Education Networks as an Illustration. Social Networking, 6, 224-238. https://doi.org/10.4236/sn.2017.63015

[69] Theoharis, D. and Bekiari, A. (2016) The Influence of Mathematics and Learning Environment in Verbal Aggressiveness and Interpersonal Relations: A Dynamic Analysis of Social Networks. Proceedings of the 8 th International Congress Mathematical Society, Thessaloniki, 30 March-3 April 2016, 415-428.

[70] Theoharis, D. and Bekiari, A. (2017) Applying Social Network Indicators in the Analysis of Verbal Aggressiveness at the School. Journal of Computer and Communications, 5, 169-181. https://doi.org/10.4236/jcc.2017.57015

[71] Theoharis, D. and Bekiari, A. (2018) Dynamic Analysis of Verbal Aggressiveness Networks in School. Open Journal of Social Sciences, 6, 14-28.

https://doi.org/10.4236/jss.2018.61002

[72] Láng, A. and Lénárd, K. (2015) The Relation between Memories of Childhood Psychological Maltreatment and Machiavellianism. Personality and Individual Differences, 77, 81-85. https://doi.org/10.1016/j.paid.2014.12.054

[73] Talwar, V. and Lee, K. (2011) A Punitive Environment Fosters Children's Disho- 
nesty: A Natural Experiment. Child Development, 82, 1751-1758.

[74] Locke, K.D. and Christensen, L. (2007) Re-Construing the Relational-Interdependent Self-Construal and Its Relationship with Self-Consistency. Journal of Research in Personality, 41, 389-402. https://doi.org/10.1016/j.jrp.2006.04.005

[75] Corzine, J.B. and Hozier, G.C. (2005) Exploratory Study of Machiavellianism and Bases of Social Power in Bankers. Psychological Reports, 97, 356-362. https://doi.org/10.2466/pr0.97.2.356-362

[76] Bereczkei, T. (2015) The Manipulative Skill: Cognitive Devices and Their Neural Correlates Underlying Machiavellian's Decision Making. Brain and Cognition, 99, 24-31. https://doi.org/10.1016/j.bandc.2015.06.007

[77] Cranmer, G.A. and Martin, M.M. (2015) An Examination of Aggression and Adaption Traits with Moral Foundation. Communication Research Reports, 32, 360-366. 